\title{
Analysis of the Spread of the University Brand in the "Internet +" Era
}

\author{
Liang Rui ${ }^{1}$ *, Kseniia Blumska ${ }^{1}$, Song Feiqiong ${ }^{2}$ \\ ${ }^{1}$ Postgrauate Student, Henan Institute of Science and Technology, Sumy National Agrarian University \\ ${ }^{2}$ School of Economics and Management, Sumy National Agrarian University, Sumy, Ukraine \\ ${ }^{3}$ College of Education, Henan Institute of Science and Technology, Xinxiang, China
}

Keywords: "Internet +" era; University brand; Communication

\begin{abstract}
The popularization of university education, the transformation and marketization of universities have intensified the competition among universities, how to carry out effective university brand marketing, and the spread of university brands. The "Internet + " era is both an opportunity and a challenge to brand marketing. By understanding the university brand and analyzing the characteristics of the university brand, the "Internet +" era background, analyzing the communication methods of the "Internet +" era university brand, "Internet +" era university, this paper aims to provide a theoretical support for the university brand to establish a good brand image, expand its popularity, improve its reputation, and gain competitive advantage.
\end{abstract}

\section{Introduction}

The progress of science and technology and the development of the Internet are gradually changing the modern society, especially the emergence of "Internet +", "Internet + education", the use of big data and cloud computing, these new things are impacting the traditional education development methods and education industry marketing. The emergence of "Internet $+"$ is precisely the concrete manifestation of profound changes in Internet technology. Internet technology is undergoing a profound transformation of social relations and people's lifestyles and ways of thinking, and its influence permeates all aspects of society. Only by adapting to the laws of market development, effectively using modern technological information, establishing brand marketing awareness, and promoting the brand image of the university, can the university brand establish a fast, efficient, and reasonable marketing channel with consumer groups.

\section{Literature Review}

\subsection{University brand}

The university brand refers to the reputation and reputation formed by the university in the long-term development process of the university's running level, scientific research level, discipline construction, teaching quality, etc., which are condensed in the name of a university. The degree of social recognition goes through time and space. The university brand includes university attributes, personality, culture, consumer interests, student evaluation, etc. Just like different types of goods have different brands, different types of universities have different brands [1].

\subsection{Characteristics of university brand}

Representation of the brand. The university brand is composed of a set of appearance information such as name, mark or design. Such appearance information must be reflected externally by the brand's deep connotation and must be consistent with the brand's connotation.

The deep connotation of the brand. The deep connotation of the brand refers to the brand's values, cultural orientation, personality characteristics and spiritual endowment. Only when the brand has a profound connotation can it form a personality assignment.

Brand recognition function. The organic combination of the appearance and connotation of the brand has shaped the special character of the brand, with clear and indistinguishable differences 
from other brands.

Consumer evaluation. The definition of the brand is ultimately done by consumers. The brand is built with consumers as the center, and it is necessary to pay attention to consumers' perception and evaluation and establish a lasting and stable relationship with them [2].

\section{3 "Internet +"}

"Internet +" first appeared in the Fifth Mobile Internet Expo in 2012. Its basic concept is to use Internet technology. The platforms and information and communication technologies that various industries can build through the Internet, which can be combined and integrated to create a new field. The ultimate goal is to give full play to the resource integration role of the Internet in the allocation of factors, through the interconnection and deep integration of different industries, more rational use of existing resources, and create a new economic ecology that is more in line with market requirements and consumer demand.

\section{Analysis and Discussions}

If the quality of a product is excellent, it is necessary to make the society widely known through brand communication, so that more customers can understand their brand value. To this end, high effect establishes a good social image in the society through brand CI planning, brand marketing, brand public relations, etc., through its own standardized brand identity, especially the outstanding performance of the students trained in various social positions. For the school's brand, our family value component, to form an efficient and unique brand effect in the society, so that customers in a certain range of markets recognize that the students they cultivated, the scientific research results provided by the university and the means of serving the society are superior to other psychological implications of colleges and universities. Once this kind of psychological suggestion becomes a kind of psychological consciousness, the social recognition of the university brand will be greatly improved, and its market brand effect will form a market brand with unique value due to the use and spread of the brand.

Through the Internet, people can transfer various types of information, such as text-based text information, audio-type audio information, and video-type audio information. The timely and interactive exchange of information has become the biggest function of the Internet. At the same time, the Internet has increasingly become an extremely important carrier of brand communication, and an important link between brands and customers or other stakeholders.

\subsection{The method of spreading university brand in the "Internet + " era}

According to Al. Rees and Laura Rees [3], if you use the Internet to build an existing brand, you should mainly treat the network as a carrier; while building an existing brand through the Internet, you should treat it as a business. Because of the particularity of the university brand, we mainly explain how to use the Internet to spread the university brand from the perspective of the carrier.

You should continue to use the existing brand name instead of creating a new brand name. Otherwise, it will cause confusion for consumers. The university brand should dig deeper into the connotation and substance of the university brand, and publicize and market the external expression of the university brand connotation and substance through the Internet.

Today's universities are adhering to the "open" attitude of running schools. The marketing of the university brand is more through the school's official website. It is particularly important to design, produce and manage websites that reflect the characteristics of the brand. The website's colors, fonts, and patterns should reflect the personality and culture of the university brand; provide navigation and search services; be interactive, not just provide information; be easy to use, and not give people a messy feeling; download speed should be quickly, pay attention to updating the content frequently.

Use multiple Internet carriers to communicate with consumers. Simply using the university's official website is far from satisfying the communication effect of university brands. More university brands use Wei Bo, We Chat, live broadcast and other network carriers to build 
communication channels between the Internet and consumers.

Take advantage of the strong integration of the Internet, and actively carry out various brand communication activities such as online advertising, online public relations, online sponsorship and online events on the Internet, and play the coordination role of various media to allow consumers to experience the university brand from many aspects.

\subsection{The role of the university brand in the "Internet +" era}

University brands spread faster. With the continuous development of Internet technology, the advent of the $5 G$ era, the rapid development of mobile Internet technology, coupled with the continuous update of software development technology, making the spread of the brand faster. This rapid transmission speed has made the relatively closed university brand communication more public, efficient, and even "amplified". Now, if a university brand has a problem, it can be spread all over the world in a few hours, and the problem the larger, the faster spread. Therefore, from this aspect, the rapid communication speed is two-way for the spread of university brands. The creation of university brands is not easy, the risk is greater than before, the ability to manage is higher, and the ability to manage brand crisis is also higher.

The spread of university branding is wider. People around the world can understand the connotation, significance, development, current situation and future of the university brand by browsing university brand websites, public accounts, Weibo and other Internet carriers anytime, anywhere, and through "products", such as the quality of graduate employment. The embodiment of the social service function forms a brand benefit and is widely spread in the society in the form of Internet information.

Increased consumer initiative. Consumers, university students, parents, businesses, and society of the university brand have gradually changed from passively receiving the information of the university brand to proactively understanding the information of the university brand, and then decide whether to "consume". People can formulate the products or services they need through the Internet, and the affinity of the university brand is gradually increasing.

The interaction between university brands and consumers has increased. The Internet allows more university brands to "go out", pay more attention to brand communication, and maintain the brand image. And consumers of university brands are also more likely to embrace such ideas through the Internet, experience the charm of the brand, and form good interactions, which also lay a solid foundation for the further spread of the university brand.

University brands are more integrated. The Internet can integrate brand communication tools, organically integrate advertising, marketing public relations, and event marketing sponsorship communication methods to exert a comprehensive effect and allow consumers to experience the university brand in a comprehensive and systematic manner.

The communication cost of university brands is lower. Due to the wide spread of the Internet, the long communication time, and the timeliness of the communication, consumers' opportunities for exposure to university brands are increasing. Therefore, relatively speaking, its communication costs have decreased.

\section{Conclusion}

All in all, the marketing of university brands has entered the Internet era. "Internet + education" is also the main channel and the development trend of university brand marketing and university brand communication in the future. In the context of the Internet era, competition in the education market is also becoming more and more exciting. University brands must use the communication method of the "Internet +" era to integrate the tangible and wireless resources of their own, which will play the role of communication in the "Internet +" era, and establish a good university. Brand image, expand visibility, improve reputation, and gain a competitive advantage. 


\section{References}

[1] Xu. T.W. (2008). Brand Strategy of Universities. (1st.de.). BeiJing: Higher Education Press, 148.

[2] Yu. M.Y. (2009.08). Brand Strategy. (10th.de.). BeiJing: Tsinghua University Press, Beijing Jiaotong University Press, 426.

[3] Al. Rees, Laura Rees.11 Rules for Building Online Brands. Mei Qinghao, translated. Shanghai: Shanghai People' s Press, 2002. 